\title{
The Socio-Political Magnitude of Humanism of Swami Vivekananda
}

\author{
Dr. Rahul Ranjan \\ Ph.D. in Political Science \\ 11A, Sewa Sadan Mandawli, \\ Fazalpur, Delhi-92 \\ Email-drrahulranjandelhi@gmail.com
}

\begin{abstract}
Between 1872 and 1886, when Sri Ramakrishna took his last breath, Belur became a new pilgrimage for people from all walks of life, from the upper classes of English educated Bengalis to the completely uneducated, and Sri Ramakrishna filled the spiritual thirst of everyone who came with true desire. But it was unusual that Sri Ramakrishna's first pick was young people, mostly English educated, and he became the backbone of his spiritual teachings and disseminated his message to the entire globe. Sri Ramakrishna selected Narendra Nath Datta, or simply 'Noren,' as their leader, and he charged all of these young people with forming a new band of Sanyasins to disseminate the word of Vedanta to every part of the globe. Swami Vivekananda was inducted into his new function by Sri Ramakrishna following a roughly six-year spiritual training from 1881 to 1886 . Armed with all of Sri Ramakrishna's divine energy, which he received at Kashipur when he took a vow to fulfill the work of 'Mother' (Divinely ordained task), he ready himself for the new chosen duties, the task of spreading the forest philosophy of Vedanta, the man-making philosophy of the old Indian system, which was held hostage by a few Sanskrit-knowing priests. Swami Vivekananda was a bridge figure among both East and West because of his English education, prior Brahma Samajist connection, and spiritual instruction under Sri Ramakrishna. After reviewing the existing socio-religious and economic situation for nearly seven years (August 1886-May 1893) and visiting every nook and cranny of the country, he discovered that the country was drenched in deep dogmatism, superstition, and ignorance spread in the name of religion, and was more dead than alive. People's thoughts were captivated with local rituals and superstitions in the guise of spirituality and religion, and they
\end{abstract}

CPerception Publishing House, 2021. This Open Access article is published under a Creative Commons Attribution NonCommercial 4.0 International License https://creativecommons.org/licenses/by-nc/4.0/, which permits non-commercial reuse, distribution, and reproduction in any medium, provided the original work is properly cited. For citation use the DOI. For commercial re-use, please contact editor @ email:- thecreativelauncher@gmail.com 
were thoroughly immersed in lethargy and unable to accomplish any real work. Slavery for hundreds of years and the imparting of British education had permanently shattered their confidence. People's physical power has been reduced by abject poverty, preventing them from having higher and noble thoughts.

Keywords- Swami Vivekananda, Humanism, India, America, Vedanta

\section{Introduction}

The year 1886 is a defining moment in the life of Swami Vivekananda. After the demise of Ramakrishna, Swami Vivekananda was going starting with one corner then onto the next corner of the country, as ravenous, barefooted meandering priest, wandering uninhibitedly with no sureness or affirmation of food or asylum, here and there with no nourishment for 4-5 day, in some cases in royal residences of Kings, some of the time is helpless' hovels and surprisingly in some cases under the tree, since most recent seven years. He made a trip from the Himalayas to Cape Comorin, for the most part by walking, and came to know India in her multicolored viewpoints, her eminence, as well as her dilapidation. He trekked generally in fictitious names and came into contact with a wide range of men. Rajas and Maharajas turned into his followers and admirers, and he felt that the untouchables-the pariahs - were his life-blood, his brothers. He had a spectacular disclosure when arriving at Cape Comorin, the southernmost tip of India. His heart was loaded up with distress when he recollected her previous greatness and her current dilapidation. "He found out that it was the age-old oppression of the poor and the humble by the upper classes which was at the root cause of India's downfall and degeneration.”[1]

Object of his rumination at the stone of Kanyakumari, was not any God seating in the paradise but rather the past, present and eventual fate of India, its previous glory and present degeneration and starving millions from individuals with no future expectation, sinking every single day in the obscurity of obliviousness and precipitate quietus. Each second his brain was intellectually engrossed by this idea. Does a true and gracious God truly exist? Why here is such a lot of anguish, yearning and outrageous destitution in our country?

The Swami Vivekananda sorrowful soul looked for an exit plan. The principal thing we need is the men, and the following is resources. The quick reason for his visit to America was 
looking for help for the poor of India. "Through the grace of our Guru I was sure to get from ten to fifteen men in every town of India. I next traveled in search of funds, but do you think the people of India were going to spend money? Selfishness personified- are they to spend anything? Therefore I have come to America, to earn money myself, and then return to my country and devote the rest of days to the realization of this one aim of my life." [2]

In his Parmakudi allocution, Swami Vivekananda addressed; "That you are here today to welcome one who went to Europe to preach Vedanta would have been impossible had not the materialism of Europe opened the way for it. Materialism has come to the rescue of India in a certain sense by throwing open the doors of life to everyone, by destroying the exclusive privileges of caste, by opening up to discussion the inestimable treasures which were hidden away in the hands of a very few who have even lost the use of them. Half has been stolen and lost; and the other half which remains is in the hands of men who, like dogs in the manger, do not eat themselves and will not allow others to do so."[3]

\section{Universalism: Swami Vivekananda a link among East and West:}

Swami Vivekananda is a connection between East and West. He was all around prepared in Western instructive framework, culture and thinking. Swami Vivekananda graduated from the University of Calcutta. His schooling and almost four years visit to America and Europe and great compatibility with each prominent contemporary figure from each follower, craftsmanship, science and religion, and layman, advanced his knowledge and his basic psyche, similar to those of westerners, was not effectively prepared acquiescence before any kind of power. He was a totally westernized man prior to coming in touch of Sri Ramakrishna. Mr. Shankari Prasad Basu says; "In an informal meeting, Swami Nikhilananda, half-humorously remarked, "Swami Vivekananda was America's gift to India."[4]

Josephin MacLeod considered the proliferation of Swami Vivekananda message in the west as her extraordinary responsibility. After the flare-up of World War II, she wrote "I am not inclined to go to War zone, in India or Europe, and as Swami Viveknanda says, 'My work will be more in the West; thence it will react on India.' I may help more in U.S.A. than in India. Now there are hundreds interested in Indian spirituality in U.S.A.; they will grow to thousands, and then millions, and as America is becoming the leading country, its influence will react on the world" (March, 6,1940). ${ }^{[5]}$ 
We find that Swami Vivekanada gave his message of Veadanta to whole world, in India the message was in our idioms and analogies Vedas, Upnishads, Gita, Ramayana and Mahabharata's story citing unique Sanskrit refrains. And in the West a similar message shrouded in language of science and similitude, images and colloquialisms utilized which were not unfamiliar to them, he put whole way of thinking of Vedanta in basic English language, so they can feel and acknowledge it as their own. This was not a simple assignment. After the incomparable Acharyas like Shankar, Ramanuja and old Vedanta Acharyas, we track down a New Shastra, another Bhashya (discourse) on Vedantic Prasthanatrayi which is totally in English language and so tremendous that it can't be restricted to the limits of a specific race, religion, order, sex, or country. It is just about as immense as the sky and none has selective case over it, it is for whole humankind. He composed Rajayoga, Karmayoga, Jnanyoga and Bhaktiyoga in book structure, deciphering the Vedantic writing in English and conveyed impromptu talk, covering almost 4,000 pages (distributed till now in 9 volumes!) which were recorded by committed American admirers (by 'my faithful Goodwin') of Swami Vivekanada and the whole humankind, especially India should be appreciative for this respectable motivation. In 150 years, this writing has expanded to whole globe on paper structure, yet every structure, sound, video and text, because of web upheaval. It is expanding over the whole globe. It is America, not the India which is assuming greatest part for this respectable purpose as it was chosen for this job by Swami Vivekananda. He did it deliberately and had effectively anticipated this; "My work will be more in the West; thence it will react on India. I may help more in U.S.A. than in India."

\section{New Gospel of Man Making:}

Swami Vivekananda said; by no means overlook the magnificence of human nature. "We are the greatest God that ever was or ever will be. Christ and Buddhas are but waves on the boundless ocean which I am." ${ }^{[6]}$ Is this affirmation of Swami Vivekananda about people is an assertion of truth or mere poetic fiction or hallucinatory imagination? 'No', it is not fiction but rather is an assertion of truth declared after the acknowledgement of reality with is us by Swami Vivekananda.

According to Swami Vivekanada: "Man making is my mission of life. I am not a politician, nor am I a social reformer. It is my job to fashion man... I care only for the spirit; 
when that is right everything will be righted by itself." Swami Ranganathanada had conveyed a talk at the Moscow State University. In this talk, he has featured the highlights of Vedantinc Humanism of Swami Vivekananda. He says; "Man's solidarity and information can be either ruinous or valuable: they can give him and his kindred people life and love, and euphoria and harmony or passing and disdain, distress and unfulfillment. Which of these two men will pick will essentially rely upon the profound turn of events, the cognizance level, that he has achieved, and just optionally on his monetary and social turn of events. It is unmindful today that financially exceptionally created social orders can cultivate, can't escape from, distance, depression, and wrongdoing; however the other truth isn't so unaware, yet India's experience shows it, that destitution and wrongdoing need not go together, that neediness of the pocket need not generally mean destitution of heart. "A humanism that is strengthened and sustained by the ignition of the divine spark in man is far different from the current humanism of the West, including its scientific humanism." [7]

The Preamble of UNESCO says; "Since war begins in the minds of men, it is in the minds of men that the defence of peace must be constructed." Vivekananda's Vedantic humanism completely supports this notion. What is required for the foundation of world harmony and the working of a widespread and dynamic humanism is the defeating of the brutality in man, through schooling being conveyed past the scholarly to the otherworldly elements of his being. This is the thing that Vivekananda calls genuine religion, which he characterizes as 'the appearance of holiness effectively in man'.

\section{The Sociological thoughts}

As per Swami Vivekananda Varna division of Bhagavad-Gita into Brahmins, Kshatriyas, Vaishyas and Shudras are the social base of Hinduism. It was an adaptable and regulating framework. Later on, it turned out to be an excess of unbending and declined into rank framework dependent on birth.

\section{Cyclic caste rule doctrine of Swami Vivekananda:}

As has been stated over that human culture isolated in the four positions the worshipper (Brahmins), the soldier (Kshatriyas), the merchants (Vaishyas ) and the labourer (Shudras ) Each state has its magnificence just as imperfections. At the point when worshipper (Brahmin) rules, there is huge eliteness on inherited grounds, the people of the priests and their relative are hemmed in with the entire type of safeguards-none, however, 
they have any information none yet they reserve the privilege to bestow that information. Its wonder is that this period is established the framework of science. The worshipper develops the brain, for through the psyche they administer ${ }^{[8]}$

The tactical principle (Kshatriya) is domineering and merciless yet they are not selective, but rather during that period expressions and social culture accomplish their tallness. The business (Vaishya) rule comes next. It is dreadful in its quiet smashing and parasitic force. Its benefit is, as the trader himself goes all over the place, he is a decent disseminator of thoughts gathered during the two previous states. They are still less selective than the military, however, culture starts to rot.

In the last will come the worker (Shudras) rule. Its benefit will be the dispersion of actual comforts, its disservice, (maybe) the bringing down of culture. There will be a great distribution of ordinary education, but extraordinary geniuses will be less and less. ${ }^{[9]}$

It very well might be asked: what is the Ideal State taking into account Swami Vivekananda? As indicated by him; "It is possible to form a state in which the knowledge of priest period, the culture of the military, the distributive spirit of the commercial, and the ideal of equality of the last can be kept, minus their evils, it will be an Ideal State." [10]

\section{Society: Culture and Civilization:}

Culture is, it appears, a more exhaustive idea than civilization, it is a very natural framework, of which material accomplishments, family association, financial association, political association, custom, religion, reasoning, morals, science, workmanship each conceivable inventive articulation of man, are parts. ${ }^{[11]}$

As per Swami Vivekananda entire of the Asian Civilization was first evolved on the plains, close to huge waterways and on fertile soils-on the banks of the Gangâ, the Yangtze-Kiang, and the Euphrates. The first establishment of every one of this progress is agribusiness, and in every one of them, the Daive nature prevails. Most of the European civilization, on the other hand, originated either in hilly countries or on the sea-coasts-piracy and robbery formed the basis of this civilization: there the Asuri nature is preponderant. ${ }^{[12]}$

In Europe, political thoughts from the national harmony. In Asia, sacred principles form national unity. In antiquated India the focal point of public life was consistently scholarly and profound and not political. Of old, as now, the political and social force has been constantly subjected to profound and scholarly. The upheaval of public life was around 
universities of sages and profound educators. We subsequently discover the Samitis of the Panchalas, of the Kashyas (of Varanasi), the Mithilas standing out as incredible focuses of profound culture and reasoning, even in the Upanishads. Again these centers in turn became the focus of the political ambition of the various divisions of Aryans. ${ }^{[13]}$

The base of India's social order is caste law. I am born for the caste and live for the caste... Born in the caste, the entire life ought to be lived according to caste principle. In other words, in the present-day words, the western man is born individualistic, while the Hindu is socialistic-entirely socialistic. "We are socialistic, for the sake of one man's or woman's exquisite pleasure we do not want to load misery on hundreds of others." [14]

\section{Society: Nature and functions:}

Swami Vivekananda has demystified the reason for our backwardness and the reason for being crushed by Western forces. As indicated by Swami Vivekananda it is a feeling of unity, patriotism and schooling of the masses. We needed both these things in the nineteenth century. We did pay the least notice to Swami Vivekananda in regards to the development of mass schooling. Our Parliament required the greater part century to understand this reality and passed the "Right to Education Act." Be that as it may, in any case, appears to be a far off dream for us and we are far away from the universalization of training for which our Swami Vivekananda wept. The following thing for which Swami Vivekananda needed to go to America was the neediness of the majority. The twin evil spirits of neediness and obliviousness are as yet alive and we have not had the option to uncover it even following seventy years of opportunity. Our genuine respect for Swami Vivekananda is totally annihilated obliviousness and neediness of the majority, for which he voyaged the whole globe and shed tears. Simple contribution blossoms and incense sticks and taking a selfie of his photo isn't adequate yet rather it would add up to offending the incredible soul.

\section{Education: Women and Depressed Class, Technical and spiritual:}

As indicated by Swami Vivekananda, "Education isn't the measure of data that is placed into your mind and goes crazy there, undigested for your entire life. We should have life-building, man-production, character-making the absorption of thoughts. On the off chance that you have absorbed five thoughts and made them your life and character, you have more education than any man who has by heart an entire library. - "the ass conveying its heap of sandalwood knows just the weight and not the worth of the sandalwood." If education 
is indistinguishable with data, the libraries are the best sages on the planet, and the reference books are the Rishis. The ideal, therefore, is that we must have the whole education of our country, spiritual and secular, in our own hands, and it must be on national lines, through national methods as far as practical." [15]

Education is the manifestation of perfection existing in man, he continues. We can't teach someone something they don't already know. It may seem strange, yet it is true. So, if everything is already within the individual, what is the use of education? Is it possible that all educational institutions will not become a waste of time? These claims are without credibility. Man has all he needs, but that does not imply he is conscious of what he has. So each person has the ability to become a scientist, a doctor, an engineer, or a statesman, but how many people are capable of achieving their dreams? We find ourselves unable to realise our best extent. Self-realization and the end of life are synonymous with $100 \%$ actualization of our potentiality. When we know who we are, there is nothing left to accomplish. It requires a lot of effort and commitment. The goal of education is to eliminate the obstacles (ignorance) and impediments that prevent manifestation. Every step we take in this manner eliminates one by one these roadblocks.

The decline of India was due to the apathy of the poor and lack of respect for women, Swami Vivekananda states. He studied the reasons for the West's success and arrived at the conclusion that the only explanation for the West's development is education, education, and more education. It was fashionable at the time to believe that India's collapse and enslavement were due to its religion, but Swami Vivekananda believed the contrary. He claims that the situation was just the opposite. Religion was limited to only a few hands, and those uneducated individuals did not know much about it. There was no flaw in our faith. India has no future unless religion is resurrected. We chose our course thousands and thousands of years ago, and there is no option for us to reverse it now; after all, it was not a horrible choice.” Religion as a tool for man-making:

We must maintain control over the nation's spiritual and secular education. Do you get what I'm saying? You must imagine it, talk about it, think about it, and put it into action. There is no hope for the race till then.

\section{State and the government}


West is groaning under the tyranny of Shylocks, and the East is groaning under the tyranny of priests; each must keep the other in check. ${ }^{[16]}$ The political system for which we are fighting in India has existed in Europe for centuries, has been tried and tested, and has been found unsatisfactory. One after the other, political structures, structures, and everything associated with them have been declared obsolete, and Europe is restless, unsure where to turn. The tyranny of material possessions is enormous. A country's riches and power are held by a few guys who do not work but control the work of millions of people. They have the ability to flood the entire earth with blood with this strength. Religion and all things are under their feet; they rule and stand supreme. The Western world is governed by a handful of Shylocks. All those things that you hear about - constitutional government, freedom, liberty, and parliaments — are but jokes. ${ }^{[17]}$

Swami Vivekananda was interviewed by a reporter from the Sunday Times of London in 1896 while he was in London, and the reporter stated to Swami Vivekananda, "I believe there is a distinction between the wisdom of the East and the wisdom of the West. Sanyas, concentration, and other techniques are used to create near-perfect humans. Now, the West's aim appears to be the perfection of the social state; as a result, we concentrate on political and social issues, believing that the survival of our civilization is contingent on the well-being of the people." Swami Vivekananda responded by saying: "The basis of all systems, social or political, rests upon the goodness of men. No nation is great or good because Parliament enacts this or that, but because its men are great and good. I have visited China which had the most admirable organization of all nations. Yet today China is like a disorganized mob because her men are not equal to the system contrived in the olden days. Religion goes to the root of the matter. If it is right, all is right. ${ }^{[18]}$

Swami Vivekananda emphasizes more differences between the goals of personal and societal growth. They appear to be diametrically opposed poles that can never meet. The West's ideal is societal upliftment through collective consciousness combined with complete individual liberty. The East's ideal is self-improvement and self-realization. Individual mind and social psyche are not two distinct entities. They are two sides of the same coin, therefore the difference between them is just visible. "There is a law that is beyond all governments," he argues. People frequently strive for the same goals without realizing it. Law, governance, and politics are all phases that are not definitive in any sense. There is a purpose beyond them 
for which no legislation is required. By the way, the name Sanyasi literally means "divine outlaw," or "divine nihilist," but misinterpretation follows people who employ such a term. The same idea is taught by all great Masters."Christ saw that the basis is not law, that morality and purity are the only strength. As for your statement that the East aims at higher self-development and the West at the perfecting of the social state, you do not of course forget that there is an apparent Self and a real Self." [19]

\section{Conclusion}

Swami Vivekananda observed millions of hungry people without a future hope, plunging every day in the darkness of ignorance and early death, with his necked eyes. Alas! None of them appears to be concerned; none appear to be troubled by their situation. His mind was always engaged with this notion. Is there a God who is both honest and merciful? So, why does our country have so much pain, hunger, and terrible poverty? Can there be an effect without a reason, my brother? I've travelled all over India and visited this nation (America), can there be an effect without a reason? Is it possible to get a penalty without committing a crime? ... I couldn't sleep, my brother, because of all of this, especially the poverty and stupidity. It's insane that there are so many Sanyasins walking about teaching metaphysics. Isn't it true that our Gurudeva used to remark, "An empty stomach is no good for religion"? That those poor people are leading the life of brute is simply due to ignorance. We have for all ages been sucking their blood and trampling them under foot." ${ }^{[20]} \mathrm{He}$ travelled to every region of India in search of material backing for his cause, but he was unable to find any. Disillusioned and heartbroken, he took the decision to seek assistance from the West. Swami Vivekananda began his career in the United States. He had firsthand knowledge of India's socio-economic realities, and his four-year stay in America improved his understanding of Western culture and society. He didn't say anything about consumerism. Both spirituality and materialism are necessary for society's healthy growth. Excessive criticism of materialism led to India's mistake, while Western people are so engrossed in materialism that they criticise everything linked to religion. He admired the west's worldly success and encouraged Indians to sit at their feet to learn materialism, while also advising Westerners to learn spirituality from India. The only way to save each other is to work together. Swami Vivekanada praised Western material growth in his Parmakudi lecture, saying, "That you are here today to greet one who travelled to Europe to preach Vedanta 
would have been unthinkable had it not been for Europe's materialism opening the way." In a sense, materialism has rescued India by throwing open the doors of life to everyone, by eliminating caste's exclusive privileges, and by exposing the incalculable wealth that had been kept away in the hands of a select few who had even lost the ability to use them. Half has been stolen and lost; and the other half which remains is in the hands of men who, like dogs in the manger, do not eat themselves and will not allow others to do so. ${ }^{[21]}$ Swami Vivekananda's Vedantic humanism emphasises religious concord. "I am glad to belong to a faith that has taught the world both tolerance and universal acceptance," Swami Vivekananda remarked in his Chicago Address. Not only do we believe in global tolerance, but we also think that all faiths are true. I am pleased to be a citizen of a country that has harboured persecuted and displaced people of all faiths and from all corners of the globe. I am pleased to inform you that we have collected in our midst the last of the Israelites, who fled to Southern India and sought shelter with us in the same year that their sacred temple was destroyed by Roman oppression. I am proud to be a member of the faith that has protected and nurtured the last remnants of the great Zoroastrian country I'll mention to you, comrades, a few words from a hymn that I remember singing since I was a child and that is sung every day by millions of people: "As the different streams having their sources in different places all mingle their water in the sea, so, O Lord, the different paths which men take through different tendencies, various though they appear, crooked or straight, all lead to thee." 22 "Sectarianism, prejudice, and its terrible offspring, fanaticism, have long controlled our lovely earth," he said. They have wreaked havoc on the planet, drenching it in human blood on a regular basis, destroying civilization and plunging entire nations into despair. Humans would not exist if it weren't for these dreadful creatures.

\section{References}

1. Basu S.P. and Ghosh S.B, Vivekananda in Indian News Papers: (1893-1902), Bhattacharya and Co., Calcutta, 1969, p-xix

2. Vivekananda Swami, Letters of Swami Vivekananda, Advaita Ashrama, Mayavati, Champavat, 2013, p-8

3. Ibid,p-6 
4. Basu S. P. and Ghosh S. B, Vivekananda in Indian News Papers: (18931902), Bhattacharya and Co., Calcutta, 1969, p. ix

5. His Eastern and Western Admirers, Reminiscences of Swami Vivekananda, Advaita Ashram, Mayavati, Champavat, 2008, p-44

6. Swami Vivekananda, Complete Works of Swami Vivekananda, Advaita Ashram, Mayavati, Champavat, Vol.VII, 2001, p-7

7. Swami Rangnathananda, Swami Vivekananda His Humanism, Advaita Ashram, Mayavati, Champavat, 2000, p-46-47

8. State Society and Socialism, Advaita Ashram, Mayavati, Champavat, 2008, P-59-60

9. Ibid,. P-59-6

10. Vivekananda Swami, Complete Works of Swami Vivekananda, Advaita Ashram, Mayavati, Champavat, Vol.VI,2001, p-38

11. Santwana Dasgupta, Social Philosophy of Swami Vivekananda, Ramakrishna Mission Institute of Culture, Gol Park, Kolkata, 2005, P-160

12. State Society and Socialism, Advaita Ashram, Mayavati, Champavat, 2008, p -6

13. Ibid,p-7

14. Swami Vivekananda, Complete Works of Swami Vivekananda, Advaita Ashram, Mayavati, Champavat, Vol.VIII,2001, p-6

15. Swami Vivekananda, Lecture From Colombo To Almora, Advaita Ashram, Mayavati, Champavat, 2006, p-23

16. Swami Vivekananda, Lecture from Colombo to Almora, Advaita Ashram Mayavati, Champavat,2006, p-65

17. Ibid p-6

18. Swami Vivekananda, Complete Works of Swami Vivekananda, Advaita Ashram, Mayavati, Champavat,.Vol.V,2001, p-192

19. Ibid, p-193

20. Swami Vivekananda, Letters of Swami Vivekananda, Advaita Ashrama, Mayavati, Champavat, 2013, p-81-82.

21. Ibid, p-64

22. Swami Vivekananda, Letters of Swami Vivekananda, Advaita Ashram, Mayavati, Champavat, 2013, p-5 